NEW LITERARIA-

An International Journal of Interdisciplinary Studies in Humanities

Volume 3, No. 1, January-February, 2022, PP. 90-95

ISSN: 2582-7375

DOI: https://dx.doi.org/10.48189/nl.2022.v03i1.010

www.newliteraria.com

\title{
Subaltern perspective in Wide Sargasso Sea: An insight to the Plight of Antoinette
}

\author{
Shweta Chaudhary \& Dr. Smarika Pareek
}

\begin{abstract}
In the past few decades subaltern studies has gained much momentum. Subaltern studies draw attention towards lives of people who are denied social, political or economic access to hegemonic power of the metropolitan homeland of an empire. Jean's movement from colonial margins of Dominica to metropolitan center of England gave her new insights into the marginalised treatment a non-native is subjected to. She expressed her feelings through letters that states: "England was terribly cold when I first came there. There was no central heating. There were fires, but they were always blocked by people trying to get warm. And I'd never get into the sacred circle. I was always outside, shivering" (Rhys, 2000, p. 221). The coldness, eviction, subordination, isolation and betrayal she suffered during her stay in England and Europe is extensively portrayed through her texts Rhys through her canonical text, Wide Sargasso Sea attempts to give voice to voiceless Bertha Mason of Jane Eyre. This paper attempts to study Wide Sargasso Sea from subaltern perspective as through this text Rhys has attempted to bring forth the plight of white Creole plantation class who were compelled to live a life of an outcast in West Indies and simultaneously marginalised by native English also have been defined in the abstract.
\end{abstract}

Keywords: Subaltern, Caribbean, Emancipation, Mixed Identity, Hegemony, Inferiority.

\section{Introduction}

The term Subaltern according to the Oxford English dictionary means of inferior status; hence making it subordinate in rank, power, authority and action but the literary use of the term draws attention towards the ordinary, the average, the everyday that was neglected and was not part of big history. In literary studies the term subaltern is used to define a population excluded from hierarchical power considering them socially, politically and economically weaker. This term is coined by Antonio Gramsci, an Italian Marxist and Communist who identified social groups and people who are denied access to socio-economic institutions in order to deny them their existence and voices as a part of cultural hegemonic process. Gramsci asserted that subalterns are those underclass people of society on whom dominant powers exercise their hegemonic influence. Subaltern studies therefore become a way for historians not only to recognize various people who are historically left at subordinate position either because of their class, caste, gender, race, language or culture but also giving them voice and power after recognizing their Subalternity. Gayatri spivak in her essay "Can the Subaltern Speak", studies the depiction of subaltern in the western Culture and Literature. According to Spivak, subalterns are people excluded from the elite and whose voice is silenced. The Oppressed ones are prohibited from telling stories and stories on their behalf are told by oppressors, the one 
who got voice just like Charlotte, who depicts the character of Bertha Mason as mad Caribbean first wife of Rochester in her novel Jane Eyre. Spivak also points out that the intention of oppressors telling subaltern's stories is not concerning but speaking for subaltern gives them an opportunity to defend and strengthen their imperialistic power. It gives them a chance to reshape subaltern identities so that they are portrayed in a way that is considered appropriate in hegemonic culture. According to Dipesh Chakrabarty, subaltern studies worked towards understanding initial formation of a subordinate subject as:

The human in our ant colonial mode of thinking was a figure of sovereignty. We wanted to make the peasant or the subaltern the subject of his or her history, period. And we thought of this subject in the image of the autonomous rights-bearing person with the same access to representation in national and other histories as others from more privileged backgrounds enjoyed. (Nayar, 2015, p. 146)

Jean Rhys was born and brought up in Dominica, a former British colony with a society that encompasses extreme diversity of both European and African cultures. The topics of main concern in Rhys's text are human relationship, either between man and woman, woman and woman or apprehension about personal identity. Butler has explained Rhys' writing as an array of neglected figures, women, children, impoverished or elderly people, the sick and the 'mad' objects who failed to be recognised by society because of physical vulnerability and social instability. Jean has been a victim of the British imperial system as her white Creole identity landed her in a constant struggle for recognition. She was white, but she wanted to be black, and yet, in London, she was thought to be of mixed race. Rhys draws attention towards her fragmented and self-rejected identity in her autobiographical text Smile Please. Savory in her book on Jean Rhys has pointed:

What her story signifies is the sense of self rejection and outsider status within her own family circle which was fed perhaps both by her own subversive reaction to restrictive domestic conventions and her internalisations of the ways colonial whites were seen by others. (Savory, 1998, p. 31)

Except for these rejections, Jean Rhys has created characters that have patience and self-supporting strength. The Characters in her stories struggle and survive because they value life even when experiencing the darkest phase. Jean Rhys's fiction is an exploration of the disempowerment of women at the hands of the male oppressors. An implication of term subaltern in Wide Sargasso Sea can be understood when Rhys read Jane Eyre upon arriving in England from Dominica at age sixteen, "a very impressionable age," and she was "quite shocked" (Letters 296-97): "I thought why should she think Creole women are lunatics and all that? What a shame to make Rochester's first wife, Bertha, the awful madwoman ... she seemed such a poor ghost. I thought I'd try to write her a life" (Rhys, 2000, p. 235). Wide Sargasso Sea therefore is an empathetic attempt of a Creole writer to write a before life for Bertha Mason of Jane Eyre.

\section{Subaltern treatment of Antoinette by Black Islanders}

"So between you I often wonder who I am and where is my country and where do I belong and why was I ever born at all" (Rhys, 2000, p. 102). Antoinette was neither European, nor Black but White and West Indian, a white Creole, a background who is stamped as an outsider. Rhys has brought to life the character of Antoinette from her childhood impressions of life in Dominica. Rhys emerged as master story teller for creating effective round characters through which she conveys ideas on certain things like identity, madness and slavery. Wide Sargasso $\mathrm{Sea}$ is a text that displays Annette and Antoinette confrontation with traumatic experiences 
after the reinforcement of emancipation act when black slaves were freed from the rule of white plantation owners. Frantz Fanon through his book, The Wretched of the Earth has drawn attention towards the slave owners who suddenly lost their power and money. His book attempts to draw attention towards the physical and mental trauma colonial masters underwent as a result of this loss and mistreatment at the hands of previous slaves. The rulers of imperial power are compelled to live a life of an expatriate and have to remain silent in order to protect themselves from the hatred of freed slaves. Rhys however believes that experiencing secluded life is an ineffable trauma and intentional forgetting is a kind of trauma response that emerges as a survival mechanism. An example of this forgetting is when Antoinette, on finding Annette's horse poisoned, says: "I thought if I told no-one it might not be true. But later that day, Godfrey found him, he had been poisoned" (Rhys, 2000, p. 16). Annette, as a part of survival instinct wants to forget that they are abandoned, insulted, vulnerable and helpless, the gravity of her feelings is expressed when she says: "We are marooned" (Rhys, 2000, p. 16). The novel is carried forward by incestuous history that curses the married life of Antoinette. Antoinette felt alienated in her homeland, her feeling is quite evident when she says: "I never looked at any strange negro. They hated us. They called us White cockroaches. Let sleeping dogs lie. One day a girl followed me singing, 'Go away white cockroach, go away, go away. Nobody wants you. Go away" (Rhys, 2000, p. 20). Antoinette, Jean's West Indian heroine mirrors her broken pride of being an outcast initially in her homeland and later in England. Rhys has always said "I have only written about myself" (Rhys, 2000, p. 30). Except for the affection from Christophine Antoinette becomes a victim to hatred of black slaves who got free after emancipation act from white plantation rulers. Antoinette's for sees a trustworthy friend in Tia but is betrayed by Tia when she takes Antoinette's money, however she tries to tell Tia that these few pennies doesn't matter but she knows that Tia like her other fellow inhabitants believes something else when she thinks:

That's not what she hear, she said. She hear all we poor like beggar. We ate salt fishno money for fresh fish. That old house so leaky, you run with calabash to catch water when it rain. Plenty white people in Jamaica. Real white people, they got gold money. They didn't look at us, nobody see them come near us. Old time white people nothing but white nigger now, and black nigger better than white nigger."(Rhys, 2000, p. 21)

Later, when Antoinette comes out of the pool and realises that Tia has taken her dress, this dress exchange is a powerful metonymy used by Rhys to reflect the imposed attempt to transpose a black identity on Antoinette. However, Tia's not wearing underclothes of Antoinette because she doesn't wear any subtly reflects the ideology and intellectual refinement of Antoinette that stayed with her even if she was treated badly, as it was something black slave inhabitants were yet to discover. Rhys' deep affection for Caribbean is reflected when Antoinette even after burning of Coulibri house by black ran to Tia as she felt: "I ran to her, for she was all that was left of my life... It was as if I saw myself. Like in a looking-glass" (Rhys, 2000, p. 38). Through this jump of Antoinette Rhys attempts to create an utopian Caribbean society in which adaptation and identity of individual are blended in a way that they live beyond the margins of race, gender, class and sex in order to avoid total extinction. But that is not the way how society works the hatred that was hidden inside the minds of black slaves find a vent up through their burning of Coulibri estate and final blow came with Tia's throwing stone and avenging the trauma her fellow black with blood of old plantation owner. Another incident when Antoinette was pushed towards margin is when she was going to convent from Aunt Cora's house, a black girl and a boy with Negro's mouth start chasing her. It was almost half way when they came close to her and the girl said:

Look the crazy girl, you crazy like your mother. Your aunt frightened to have you in 
house. Your mother walk alone with no shoes and stockings on her feet, she sans culottes. She try to kill her husband and she try to kill you too that day you go to see her. She have eyes like zombie too (Rhys, 2000, p. 42).

There were several incidents in the text that demeans the existence of white plantation owners to margins. Rochester's unlinking for Christophine initiates a conversation between him and Antoinette where she mocks Justice and says:

'I've heard that word. It's a cold word. I tried it out,' she said, still speaking in a low voice... There is no justice.' She drank some more rum and went on, 'My mother whom you talk about, what justice did she have? My mother sitting in the rocking- chair speaking about dead horses and dead grooms and a black devil kissing her sad mouth. Like you kissed mine.' She said. (Rhys, 2000, p. 121)

Antoinette this outburst clearly shows her anguish as a daughter and victim of sexual exploitation both by ex-slaves and English just because both of them were white Creoles they were subjected to exploitation both by Jamaicans as well as English with no place in the world to go where they are treated with respect.

\section{Subaltern treatment of Antoinette by Colonial Masters}

Wide Sargasso Sea opens up with the feeling of being Subaltern:

They say when trouble come close ranks and so white people did. But we were not in their ranks. The Jamaican ladies had never approved of my mother, 'because she pretty like pretty self' Christophine said. She was my father's second wife, far too young for him they thought, and worse still, a Martinique girl (Rhys, 2000, p. 15).

White women disapproved of Annette as Cosway's valid wife because of her Martinique origin and held her responsible for Cosway's deterioration. However, this was not the case and Cosway sugar estate suffered because of his drinking habit and freeing of slaves as part of Emancipation act. Annette was held responsible for downfall and became a victim of these slandered conversations of white because of her mixed origin. Annette and her daughter Antoinette both become a prey to exploitation from Masons and Rochester because of the anxieties of racial mixing. Mr. Mason, Annette's second husband and Antoinette's step father, personifies pure English Victorian male full of haughtiness and colonial creed. Mason marries not out of sympathy but out of colonial greed to own Annette's property. He ignored Annette's repeated alerts to move to a safe place as she could sense the growing hatred in slaves against them but ignores her words because of his arrogance and selfish desire which result in burning and death of Pierre which results in mental breakdown of Annette as all her hopes of better future for herself and her children are shattered. Despite similarity in her looks with English masters she still was not a part of hegemonic background and culture. Ironically nothing changes for Annette's daughter also and she also becomes a victim to the selfish interest of Richard Mason, her half-brother and Mr. Rochester. Jean was disgusted by Rochester's presentation of his Caribbean Bertha in Jane Eyre as:

Bertha Mason is mad; and she came of a mad family; idiots and maniacs through three generations. Her mother, the Creole, was both a madwoman and a drunkard!--as I found out after I had wed the daughter: for they were silent on family secrets before. Bertha, like a dutiful child, copied her parent in both points (Bronte, 1905, p. 363). 
Wide Sargasso Sea becomes a text through which Rhys attempts to disclose the malicious intention of Mr. Rochester to marry Antoinette, a white Creole. According to 19 century Victorian Inheritance law, father's property is owned by the elder son due to which he was rendered landless and to compensate for the loss and arrangement of property for himself he marries Antoinette a white Creole origin in Jamaica. Therefore, in order to connect Jane Eyre with Wide Sargasso Sea Rhys frames a story explaining the marriage of Rochester to Antoinette. Actual reason behind marrying her was his selfish interest to own her property as according to 19th century law a woman's property gets transferred to her husband after marriage. Rochester is contaminated with a sense of racial and cultural hegemony, insular ignorance and visceral racism always criticizing his surroundings and perceiving it as nasty. He finds the place malevolent and is irritated when Antoinette happily confesses that this is her place and everything is on their side. Antoinette explains to Rochester the discomfort she faces in dealing with Amelie as:

It was a song about a white cockroach. That's me. That's what they call all of us who were here before their own people in Africa sold them to slave traders. And I've heard English women call us white niggers. So between you I often wonder who I am and where is my country and where do I belong and why was I ever born at all. (Rhys, 2000, p. 61)

But her haughty English husband discards her wife's emotional suffering as melodrama. At this stage Antoinette realised that though she has married English but still her Creole identity keeps her on the margins of West Indian as well as British capitalist.

\section{Conclusion}

Pauline Melville in Shape shifter has aptly stated that the paradigm, the lens through which something is viewed determines what is seen. The term Subaltern studies attempts to draw attention towards peasant and deprived class who are victims of imperial rule but analysing Wide Sargasso Sea from the perspective of race and gender clearly depicts that binary relation of subaltern and ruling class studied as interaction of dominance and subordination is not a constant phenomenon. The concept of identity and subject creation is an ever-changing phenomenon in which the roles are interchangeable as in the case of Antoinette whose identity and economic status came crashing down just because of the emancipation act. Her role is just reversed in a moment from dominant white plantation owner to one left on the mercy of Jamaican inmates. Thus, mere a change in law made them victims out of victimizers. Antoinette's gender further became a cause of her inferior status as marriage transfers all her property to her selfish English husband whose sole purpose of marrying her was to own her property. In fact, Patriarchy played a role in putting Antoinette in an undesirable situation that made her lose her senses. As a gender subaltern Annette and Antoinette endures all the suppression in Caribbean firstly at the hands of slaves and then their English their husbands. This study shows how Jean Rhys portrays the cruelty imposed on the women of mixed origin mentally, physically and socially throughout the periods of time by the patriarchal and imperial system. To be a white Creole woman in early twentieth-century Dominica is to be both Caribbean and English and neither fully Caribbean nor fully English. While appropriate locations are important for understanding the limitation of Rhys's white Creole identity, another important point that comes to the forefront is that the feminine Creole is not a static, composite culture. According to critics 'Creoleness' is a positive phenomenon of cumulative assimilation of cultural elements of Caribbean, Europe, Asia and Levantine as a result of interaction and transaction amongst them. However, the identity of Antoinette in the Wide Sargasso Sea is one 
which is constantly negotiated between two poles.

\section{References}

Brontë, C. (1905). Jane Eyre. J. Grant.

Chakrabarty, D. (2012). Postcolonial Studies and the Challenge of Climate Change. New Literary History, 43(1), 1-18. https://doi.org/10.1353/nlh.2012.0007.

Ciolkowski, L. E. (1997). Navigating the Wide Sargasso Sea: Colonial History, English Fiction, and British Empire. Twentieth Century Literature, 43(3), 339-359. https://doi.org/10.2307/441916.

Frickey, P. M. (1990). Critical Perspectives on Jean Rhys. Three Continents Press.

Bloom, H. (1997). Caribbean women writers. Chelsea House.

Mzoughi, Imen. (2016). The White Creole in Jean Rhys's Wide Saragasso Sea: A Woman in Passage. De Gruyter Open, $V$ (1), 88-110. https://doi.org/10.1515/hssr -2016-0006.

Nayar, P.K. (2015). Postcolonial Studies: An Anthology. John Wiley \& Sons.

Quayson, Ato. (2020, November 8). Jean Rhys, Wide Sargasso Sea and the Genesis of Secrecy. Critic. Reading. Writing with Ato Quayson [Video]. $\quad$ YouTube. https://www.youtube.com/watch?v=h1LJRCz5I50.

Rhys, J. (2000). Wide Sargasso Sea. Penguin Classics.

Savory, E., et al. (1998). Jean Rhys. Cambridge University Press.

Stouck, Jordan. (2001). The Feminine Creole: Identity in the Works of Jean Rhys, Alice Dunbar-Nelson and Pauhe Melvill. (Doctoral dissertation).Queen's University. https://central.baclac.gc.ca/.item?id=NQ63457\&op=pdf\&app=Library\&oclc_n umber $=1006695917$.

\section{$\underline{\text { Bio-note }}$}

Shweta Chaudhary is a Ph.D. research scholar in the Department of English, Chandigarh University, Punjab, India. Her research focuses on cultural studies and Postcolonial literatures.

Email Id: shwetdutt@gmail.com

Dr. Smarika Pareek is an Associate Professor in Department of English, Chandigarh University, Punjab, India. Her research interests include Diasporic and Postcolonial studies. Email Id: smarika.uila@cumail.in 